\title{
Book Selection in Academic Libraries
}

\begin{abstract}
Historically, most academic libraries have depended upon the faculty for the selection of library materials. Faculty representatives, appointed to deal with the library, made or approved necessary selection for a particular department of instruction. However, for one reason or another, most academic libraries have in more recent years felt the need to supplement the endeavors of the faculty through the use within the library of bibliographers and subject specialists responsible for book selection. A survey was made to determine the amount and methods of book selection within the library, and results of that survey are reported.
\end{abstract}

I $\mathrm{N}$ ORDER to determine how book selection is accomplished in larger academic libraries, a questionnaire was composed and sent to seventy selected academic libraries ranging in size from three hundred thousand volumes to over a million. ${ }^{1}$ The questionnaire sought to discover whether the library in question had librarians responsible for book selection, with what department in the library they were associated, what qualifications were desired or required, and whether or not they had different salary scales or other benefits for these specialists. Sixty-seven of the seventy libraries canvassed replied; and of these, sixtytwo were engaged in book selection. ${ }^{2}$

While most academic librarians now agree that they (librarians) should engage in book selection, there is at present little agreement on selection methods and procedures, and where such selectors should be located within the library system. The results of this survey demonstrate both agreement on the need for more book selection from within the li-

\footnotetext{
${ }^{1}$ For the purposes of this article, college, research, and university libraries will be referred to collectively as academic libraries.

"The term "book selection" as used in this article excludes the selection and purchase of reference materials and occasional general items for the library.
}

Mr. Haro is Social Sciences Bibliographer, University of California at Davis. brary and also the lack of agreement on how best to accomplish it.

Most of the larger academic libraries with firmly established area studies, or medium-sized libraries with accelerated programs for collection development, were utilizing bibliographers or subject specialists responsible for the selection of library materials. Of the libraries with over five hundred thousand volume collections, approximately 69 per cent utilized bibliographers or subject specialists who were located in the technical services or were directly responsible either to the director of libraries or to one of the assistant directors; 22 per cent of the remaining libraries within this size-class utilized the heads of divisional reading rooms or subject areas as selectors. ${ }^{3}$ Only 6 per cent of these libraries used subject bibliographers or subject specialists in reference departments as selectors. The remaining 3 per cent utilized combinations of the above or other methods. The majority of these libraries also had a pay scale for these selectors different from or higher than other librarians within the same class of position but without book selection duties.

\footnotetext{
'The term "subject-divisional arrangement" here refers to those libraries that shelve all library materials in broad subject sections, such as all social sciences materials on floor one, humanities on floor two, and etc.
} 
If employed as a selector, approximately 60 per cent of the librarians with both a library degree and an advanced degree in a subject field were on a different or higher salary scale. In libraries that located selectors in reference departments, however, 76 per cent were on the same salary scale as other librarians in that department. In addition, 56 per cent of the selectors located in reference departments received no reduction in the number of weekly hours they were required to appear at the public reference desk to allow for selection duties.

Ostensibly, selection by librarians functioning as subject specialists in reference departments or some other public services position appears an excellent and perhaps economical approach. Where the particular academic library is undergoing a period of accelerated growth and rapid collection development for new or expanded graduate and area studies programs, however, latent problems eventually demonstrate the weaknesses of such an approach. Problems of administrative control, overlapping of authority and supervision, duplication of effort by selectors and acquisition/order personnel, conflicts in reference desk duty and selection assignments, to name but a few, make the location of selectors in one of the public services departments something only to be undertaken with considerable care and planning. In-depth and expensive accelerated collection development demands block purchases, regular and sometimes extensive book purchasing trips and, obviously, considerable bibliographic competency and sophistication. If possible, librarians involved in this type of selection or collection development should be true specialists with a rich language background, graduate-level subject competence and/or have an intimate knowledge of the book business, market, and out-of-print trade. ${ }^{4}$ Of course, the choice

"Philip J. MeNiff, "Foreign Area Studies and Their Effect on Library Development," College and Research Libraries, XXIV (July 1963), 295. of location for selectors within the library system depends upon other factors, such as the size of the academic institution; size, arrangement and growth rate of the library's collection(s); expansion of curricula to include graduate programs and developing area studies; archival programs; and special collections.

The results of this survey demonstrate that most academic libraries with a subject-divisional library arrangement usually prefer to have the heads of such divisions, reading rooms, or sections function in a dual capacity as both reference librarians and book selectors, a system that is not altogether without its advantages and merits. Small libraries that do not have a subject-divisional library arrangement usually tend to favor the location of book selectors in their reference departments. Most of the larger and rapidly growing academic libraries approach the problem of book selection and the location of selectors within the library system from other directions, however, such as bibliographers in acquisition departments; curators; separate book selection or collection development departments; area specialists; or bibliographers. ${ }^{5}$

\section{SURVEY OF BOOK SELECTION IN ACADEMIC LIBRARIES}

Total Number of QUestionnaires

Sent Out

Total Number of Replies Received

Number of Libraries Engaged in

Book Selection

Types of Positions Held By SELECTORS

ubject bibliographers or subject specialists in reference departments

PER

No. Cent

Subject bibliographers or subject specialists in acquisition departments

Bibliographers (responsible only to the director or assistant director)

${ }^{5}$ Cecil K. Byrd, "Subject Specialists in a University Library," College and Research Libraries, XXVII (May 1966), 191-93. 
Heads of divisional reading rooms or subject areas (public services personnel)

\section{4}

Department heads other than in public services

Separate book selection departments

Other methods

\section{Totals}

\section{Required Qualifications} FOR SELECTORS

Library degree with appropriate undergraduate training or subject competence

Library degree with graduate work and/or advanced subject training

Library degree with an advanced degree in subject field

No library degree but with appropriate undergraduate training or subject competence .

No library degree but with appropriate graduate work or advanced degree in subject field

No required qualifications for selectors

Totals

$8 \quad 13$

$\frac{8}{62} \frac{13}{100}$

Appointments for Selectors

No. Cent

Regular twelve-month appointment with one-month paid vacation

$59 \quad 95$

Ten month appointment

35

Selectors in Public Service

PER

$\overline{62} \overline{100}$ -Reference Desk Duty

No. Cent

PER Reduced number of hours at

No. Cent reference desk allowed for selection duties

No allowance made for reduced number of hours at reference desk to perform selection

\section{$14 \quad 56$}

Selectors in Public Service -Salary Scales

PER

$12 \quad 19$

Pay differential for selectors

2134 (higher or different scale).

No pay differential for selectors

No. Cent

$6 \quad 24$

$19 \quad 76$

$23 \begin{array}{r}\text { Status of Librarians in } \\ \text { Institutions SURVEYed }\end{array}$

PER

No. Cent

Academic status for librarians . $\quad 41 \quad 62$

Faculty status for librarians $\quad 18 \quad 27$

$\begin{array}{lll}4 & 7 & \text { Other }\end{array}$

$8 \quad 11$
NotE: It is interesting to note that of the libraries that do not engage in book selection, four out of the five have neither academic nor faculty status for their librarians.

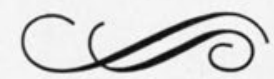

